\title{
ANTI-INFLAMMATORY EFFECT OF OBSTRUCTIVE JAUNDICE IN RATS*
}

\author{
BY \\ RONALD L. ENGERMAN AND ROLAND K. MEYER \\ Department of Zoology, University of Wisconsin, Madison, Wisconsin
}

Detailed clinical observations by Hench (1933, 1934) established that hepatogenous jaundice ameliorated rheumatoid arthritis and fibrositis. Reports followed of remissions attending jaundice induced by the injection of bile salts and bilirubin (Thompson and Wyatt, 1938), by inoculation with infectious jaundice (Gardner, Stewart, and MacCallum, 1945), and by lactophenin (Hanssen, 1942), in addition to the many remissions attributed to cinchophen toxic hepatitis. In rats also, jaundice caused by the ligation of the bile duct inhibited an experimental arthritis produced by the injection of formalin (Selye, 1950) or of pleuropneumonia-like organisms (Snow and Hines, 1941). Selye's interpretation of jaundice and arthritis in terms of stress and inflammatory processes suggested that the antiinflammatory effect of jaundice might be mediated by a hypersecretion of adrenal glucocorticoids (Selye, 1950). Subsequently, Selye (1954) provided evidence that an increased secretion of glucocorticoids is not prerequisite to a reduction of inflammatory processes during jaundice. He found that jaundice enhanced the anti-inflammatory effect of cortisone in adrenalectomized rats, and interpreted this as being due to a glucocorticoid-sensitizing principle in jaundice. A possibility that jaundice inhibited the inactivation of glucocorticoids was investigated by Baker (1955), and liver slices from jaundiced and non-jaundiced rats were found to inactivate equal amounts of hydrocortisone.

The present study was undertaken to obtain additional information about the role of adrenocortical hormones in inflammatory precesses during obstructive jaundice. Indices of adrenocortical hormone activity and inflammatory processes were the weights, respectively, of the thymus and of the

- This investigation was supported in part by Grant A-804(C8) and by a research fellowship (AF-8359-C) from the National Institute of Arthritis and Metabolic Diseases, U.S. Public Health Service. granulation tissue which formed in and about subcutaneously implanted cotton pellets. The data revealed that jaundice inhibited inflammation not only in rats with functional adrenals but also in adrenalectomized rats, and that the anti-inflammatory effect of jaundice was additive to that of cortisone.

\section{Materials and Methods}

Experimental Animals.-Male albino rats (Holtzman Rat Co., Madison, Wisconsin) were individually caged and acclimatized to the laboratory for 2 days before the initiation of the study. At the time of cotton pellet implantation all rats were 60 days old. Rockland rat diet and tap water were provided ad libitum, and adrenalectomized rats were offered in addition 1 per cent. saline as drinking water.

Jaundice.-Obstructive jaundice was produced by ligating the ductus choledochus in the region of the caudate lobe of the liver. On the initial day of the experiment the rat was anaesthetized with ether, an epigastric incision was made, and the liver lobes were retracted to expose the duct. Partial obstruction of the duct was produced by tying a cotton cord around the duct and a wire $(0.03 \mathrm{~cm}$. in diameter) parallel to it. Then the wire was removed immediately, leaving the ligature, and the incision was closed. A sham operation consisted of all the steps in the ligation technique except that the ligature was not tied. At the end of 10 days the rats were killed and the plasma icteric index (King, 1951) was measured. Duct ligation produced a severe jaundice which corresponded to an icteric index of 24 to 32 , compared with an index of 3 to 5 for sham-operated rats.

Adrenalectomy.-Bilateral adrenalectomy was performed by a lumbar approach under ether anaesthesia $72 \pm 2$ hrs after the duct ligation or sham operation. All adrenalectomized rats failed to show accessory adrenal tissue at autopsy. 
Cotton Pellet-Granuloma Tissue Technique.-Cotton pellets weighing 6 to $8+0 \cdot 1 \mathrm{mg}$. were selected from those commercially supplied for use by the dental profession, and were formed into cylindrical pellets of loosely-wound fibres. At $72 \pm 2$ hrs after the duct ligation or sham operation, each rat was anaesthetized with ether, a short medial incision was made in the pectoral skin, and a bilateral pair of tunnels was formed in the loose subcutaneous tissue. A cotton pellet was deposited in the connective tissue at the end of each tunnel and the incision was closed with a wound clip; the average of the pellet weights was $7 \mathrm{mg}$. Two more pellets were implanted in the dorso-lateral neck regions of each rat by a similar procedure. The four pellets remained in place for 7 days, and the pellets with attendant granulation tissue were then removed, trimmed of excess connective tissue, air dried for $48 \pm 2 \mathrm{hrs}$ at $75^{\circ} \mathrm{C}$., and weighed. The initial weight of each pellet was subtracted from the total dry weight of each granuloma. The average dry weight of tissue per granuloma was recorded for an individual rat; these values were used to calculate the mean dry weight of granuloma tissue and the standard error.

Hormonal Treatment.-This was initiated at the time of cotton pellet implantation; the compounds were injected subcutaneously in the pelvic area for 7 days.

Cortisone acetate (Merck) was administered at a dosage of $7.5 \mathrm{mg} . / \mathrm{kg}$./day. Since the microcrystals were suspended in an aqueous solution of carboxymethyl cellulose $(0.5$ per cent.), polyoxyethylene sorbitan monooleate ( 0.4 per cent.), and sodium chloride ( 0.9 per cent.), these ingredients, designated as Placebo-C, were injected also into rats.

Thiouracil (American Cyanamid) was injected at a dosage of $40 \mathrm{mg} . / \mathrm{kg}$./day in 0.9 per cent. saline. Thyroxine (Roche Organon Synthetic Crystals) was injected in a divided daily dose of $40 \mu \mathrm{g} . / \mathrm{kg}$. in alkaline solution. $\overline{0}$ The placebos of these preparations were designated as Placebo-U and Placebo-X respectively.

\section{Results and Discussion}

Granuloma Tissue Formation.--The validity of the cotton pellet granuloma tissue formation method as an index of inflammatory processes has been demonstrated by Meier, Schuler, and Desaulles (1950), and the method has been used in our laboratory (Meyer, Stucki, and Aulsebrook, 1953; Stucki and Meyer, 1955). Cortisone typically inhibits granu- $\vec{\oplus}$ loma tissue formation, as is shown in Table I by a comparison of non-jaundiced adrenalectomized rats which have been injected with either cortisone or the Placebo-C $(P<0.01)$.

In rats with intact adrenals, ligation of the bile $\overrightarrow{0}$ duct causes a significant decrease in granuloma tissue $\mathbb{\mathbb { D }}$ formation when compared with the effect of the sham operation $(P<0.01)$. This is not dependent entirely upon an increased secretion of glucocorticoids by the adrenals, since jaundiced rats for 8 less granulation tissue than non-jaundiced rats eve if the rats have been adrenalectomized and maine

TABLE I

EFFECTS OF BILE DUCT LIGATION, CORTISONE ACETATE, AND THYROID TREATMENT ON GRANULOMA TISSUE FORMATION, THYMUS, AND THYROID WEIGHTS IN RATS

\begin{tabular}{|c|c|c|c|c|c|c|c|c|}
\hline \multirow{2}{*}{\multicolumn{3}{|c|}{ Treatment }} & \multirow{3}{*}{$\begin{array}{c}\begin{array}{c}\text { No. } \\
\text { of } \\
\text { Rats }\end{array} \\
5 \\
5\end{array}$} & \multirow{3}{*}{$\begin{array}{c}\begin{array}{c}\text { Granuloma* } \\
\text { Dry Weight } \\
\text { (mg.) }\end{array} \\
\begin{array}{r}8.4 \pm 0.36 \\
18.4 \pm 0.48\end{array}\end{array}$} & \multirow{3}{*}{$\begin{array}{c}\begin{array}{c}\text { Thymus } \\
\text { Weight } \\
\text { (mg.) }\end{array} \\
125 \pm 53^{\dagger} \\
622 \pm 28\end{array}$} & \multicolumn{2}{|c|}{ Body Weight (g.) } & \multirow{3}{*}{$\begin{array}{c}\text { Thyroid } \\
\text { Weight } \\
\text { (mg.) }\end{array}$} \\
\hline & & & & & & Initial & Final & \\
\hline I Non-Adrenalectomized & $\begin{array}{l}\text { Duct Ligation } \\
\text { Sham Operation }\end{array}$ & $\begin{array}{l}\cdots \\
\cdots\end{array}$ & & & & $\begin{array}{l}189 \pm 2 \cdot 0 \\
198 \pm 2 \cdot 9\end{array}$ & $\begin{array}{l}177 \pm 16 \cdot 2 \\
262 \div 3 \cdot 0\end{array}$ & \\
\hline \multirow{6}{*}{ II Adrenalectomized } & $\begin{array}{c}\text { Duct Ligation }+ \\
\text { Placebo-C } \\
\text { Sham Operation } \\
\text { Placebo-C }\end{array}$ & $\begin{array}{l}\cdots \\
\vdots \\
\cdots\end{array}$ & $\begin{array}{l}6 \\
7\end{array}$ & $\begin{array}{l}11 \cdot 0 \pm 0 \cdot 92 \\
14 \cdot 8 \pm 0 \cdot 89\end{array}$ & $\begin{array}{l}491 \pm 52 \\
659 \pm 43\end{array}$ & $\begin{array}{l}186 \pm 1 \cdot 6 \\
183 \pm 2 \cdot 8 \\
\end{array}$ & $\begin{array}{l}165 \pm 5 \cdot 4 \\
199 \pm 6 \cdot 9 \\
\end{array}$ & \\
\hline & $\begin{array}{l}\text { Duct Ligation }+ \\
\text { Cortisone } \\
\text { Sham Operation } \\
\text { Cortisone }\end{array}$ & $\begin{array}{l}\ldots \\
\cdots \\
\cdots\end{array}$ & 6 & $\begin{array}{l}6 \cdot 0 \pm 0 \cdot 29 \\
9 \cdot 2 \pm 0 \cdot 31\end{array}$ & $\begin{array}{l}43 \pm 6 \cdot 4+ \\
164 \pm 82^{\dagger}\end{array}$ & $\begin{array}{l}187 \pm 4 \cdot 1 \\
190 \pm 2 \cdot 2\end{array}$ & $\begin{array}{l}149 \pm 5 \cdot 9 \\
196 \pm 5 \cdot 3\end{array}$ & \\
\hline & $\begin{array}{c}\text { Duct Ligation - } \\
\text { Cortisone - } \\
\text { Thyroxin } \\
\text { Duct Ligation - } \\
\text { Cortisone - }\end{array}$ & . & 6 & $5 \cdot 9 \pm 0 \cdot 78$ & $38 \pm 3 \cdot 4$ & $193=2 \cdot 6$ & $160 \pm 6 \cdot 8$ & $7 \cdot 3 \pm 0 \cdot 38$ \\
\hline & $\begin{array}{c}\text { Placebo-X } \\
\text { Sham Operation } \\
\text { Cortisone }\end{array}$ & $\because$ & 4 & $5 \cdot 1 \pm 0 \cdot 70$ & $35 \pm 3 \cdot 0$ & $189 \pm 6 \cdot 1$ & $154 \pm 6 \cdot 9$ & $6 \cdot 5 \pm 0 \cdot 70$ \\
\hline & $\begin{array}{c}\text { Thiouracil } \\
\text { Sham Operation } \\
\text { Cortisone }\end{array}$ & $\dot{*}$ & 5 & $9 \cdot 9 \div 0 \cdot 41$ & $141=10$ & $182 \pm 1 \cdot 7$ & $207 \pm 3 \cdot 1$ & $16 \cdot 1 \div 1 \cdot 0$ \\
\hline & Placebo-U & . & 4 & $9 \cdot 9 \pm 0 \cdot 82$ & $166 \div 17$ & $186 \pm 3 \cdot 2$ & $198=4 \cdot 6$ & $11 \cdot 4 \pm 0 \cdot 5$ \\
\hline
\end{tabular}


tained on weight-proportional dosages of cortisone $(P<0 \cdot 01)$. Jaundice has also inhibited granuloma tissue formation when adrenalectomy, pellet implantation, and cortisone treatment have been postponed until 7 days after duct ligation or sham operation $(P<0.01)$. The mean weight $( \pm$ S.E.) of granuloma tissue obtained 7 days after such treatment is $7 \cdot 9( \pm 0 \cdot 14) \mathrm{mg}$. for four jaundiced rats, compared with $10 \cdot 8( \pm 0 \cdot 11) \mathrm{mg}$. for eight sham-operated rats.

In rats deprived of both endogenous and exogenous glucocorticoids, the granulomata formed by jaundiced rats are of a significantly lower weight than those formed by non-jaundiced rats $(P<0.02)$. The administration of cortisone further reduces granuloma tissue formation in adrenalectomized icteric rats $(P<0.01)$.

In contrast to these results, other workers have reported that adrenalectomy prevents jaundice from inhibiting granuloma tissue formation in the rat (Baker, 1955; Hershberger and Hansen, 1959). The apparent contradiction is due perhaps to their having terminated their studies 5 days or less after bile duct ligation and pellet implantation, i.e. sooner than in the present investigation. This explanation is consistent with their data showing that in adrenalectomized rats jaundice inhibits inflammation but to a statistically insignificant degree. Selye (1954), utilizing the granuloma pouch and topical irritation techniques, reported that obstructive jaundice potentiated the anti-inflammatory effects of cortisone. He attributed this to an increased sensitivity of jaundiced rats to anti-inflammatory corticoids. This interpretation would fail to explain the ability of jaundice to inhibit granuloma tissue formation in the absence of glucocorticoids, as shown in the present study. The data in Table II provides a basis for suggesting that the anti-inflammatory effects of cortisone and jaundice may be mutually independent and additive. Since, in Selye's study, adrenal-

TABLE II

INHIBITORY ACTIVITY OF CORTISONE ACETATE AND/OR JAUNDICE UPON GRANULOMA TISSUE FORMATION IN ADRENALECTOMIZED RATS

\begin{tabular}{|c|c|c|c|}
\hline \multirow[b]{2}{*}{ Treatment } & \multirow{2}{*}{$\begin{array}{l}\text { No. } \\
\text { of } \\
\text { Rats }\end{array}$} & \multicolumn{2}{|c|}{ Dry Granuloma Tissue (mg.) } \\
\hline & & Weight* & $\begin{array}{l}\text { Difference in } \\
\text { Weight from } \\
\text { Control Group }\end{array}$ \\
\hline $\begin{array}{c}\begin{array}{c}\text { Control (Sham Operation } \\
\text { with Placebo-C) }\end{array} \\
\end{array}$ & 7 & $14 \cdot 8 \pm 0 \cdot 89$ & - \\
\hline $\begin{array}{l}\text { Jaundice (with Placebo-C) } \\
\text { Cortisone (with Sham }\end{array}$ & 6 & $11 \cdot 0 \pm 0 \cdot 92$ & $-3 \cdot 8$ \\
\hline $\begin{array}{l}\text { Cortisone (with Sham } \\
\text { Operation) } \\
\text { Jaundice and Cortisone }\end{array}$ & $\begin{array}{l}6 \\
6\end{array}$ & $\begin{array}{l}9 \cdot 2 \pm 0 \cdot 31 \\
6 \cdot 0 \pm 0 \cdot 29\end{array}$ & $\begin{array}{l}-5 \cdot 6 \\
-8 \cdot 8\end{array}$ \\
\hline
\end{tabular}

- mean \pm standard error. ectomized rats not receiving cortisone were maintained on deoxycorticosterone, it seems possible that the anti-inflammatory effect of jaundice was antagonized by deoxycorticosterone.

Obstructive jaundice (Telkkä and Kuusisto, 1954), or cortisone (Hirvonen and Räsänen, 1954), may inhibit thyroid function in the rat. Among the possible consequences of hypothyroidism is a decreased capacity of the liver for inactivating cortisone (Yates, Urquhart, and Herbst, 1958). A postulate that hypothyroidism contributed to the antiinflammatory effect of jaundice was therefore explored in cortisone-treated rats, by determining whether or not granuloma tissue formation was inhibited by thiouracil injections, or was increased during jaundice by thyroxin injections. The data show that administration of thyroxin to jaundiced rats maintained on cortisone does not alter the formation of granulation tissue $(P>0.4)$. Likewise, thiouracil treatment does not influence granuloma tissue formation in sham-operated rats maintained on cortisone $(P=0 \cdot 5)$. The effectiveness of thiouracil is reflected in a significant increase in thyroid weights $(P<0.01)$. Thyroid weights of rats which have been injected with thyroxin and placebo-X are statistically equivalent $(P>0.4)$; no data are available to estimate the extent to which exogenous thyroxin provided adequate therapy. The results indicate that a possible difference between jaundiced and non-jaundiced rats in availability of thyroid hormone is not responsible for the observed difference in granuloma tissue formation. The failure of thyroid treatment to modify the amount of granuloma tissue may be due to the absence of adrenal tissue in these rats. The data do not preclude interactions of thyroid and adrenal glands. Selye, Sylvester, Hall, and Leblond (1944) reported that thyroidectomy facilitated the production of joint lesions in DCA-treated rats; their results were substantiated by Harrison and Barnett (1953), who correlated the arthritis with a hypofunction of the adrenal zona fasciculata caused by the thyroparathyroidectomy.

The present study does not determine whether the effects of bile duct ligation on connective tissue formation may result from direct effects of biliary products, from effects of their exclusion from the intestine, or from changes in hepatic metabolism. Since cholesterol, like cortisone, is capable of inhibiting fibroblast proliferation in vitro (Holden and Adams, 1957), increased blood levels of cholesterol and structurally similar bile acids may have contributed to the anti-inflammatory effect of jaundice. An impairment of food intake or efficiency of utilization in jaundiced rats (Baker, 1955) 
might be conducive to the associated inhibitions of body weight and granuloma tissue formation.

Thymus.-Bile duct ligation causes involution of the thymus in rats with intact adrenals $(P<0.01)$, but not in adrenalectomized rats injected with cortisone $(P>0 \cdot 2)$. This failure of jaundice significantly to reduce thymus weight in cortisonetreated rats may be due to the severe involution caused by cortisone. A comparison between the thymus weights of placebo-C treated jaundiced and non-jaundiced rats, in which the suspected masking effect of cortisone is absent, indicates that duct ligation alone produces thymic involution $(P<0 \cdot 02)$. Although part of the involution associated with duct ligation may be residual from the interval before adrenalectomy, the thymus weight may also be modified by factors other than adrenal hormones. Dietary vitamin $B_{12}$ can influence the thymolytic effects of cortisone (Meites, 1951, 1952), and adrenalectomy may fail to prevent thymic involution if thyroidectomy has also been performed (Marine, Manley, and Baumann, 1924). While there is reason to suspect a hypothyroidism in jaundiced rats treated with cortisone, thyroid function does not appear to be implicated in the thymic involution occurring in these cortisone-treated rats, since thiouracil does not accelerate, nor does thyroxin impede the thymolysis $(P>0 \cdot 3)$. Although the factors responsible for thymic involution in jaundiced adrenalectomized rats are not clear, the results are consistent with the glucocorticomimetic effect of jaundice on granuloma tissue formation.

\section{Summary}

Obstructive jaundice in the rat inhibits the amount of granulation tissue which is induced by subcutaneously implanted cotton pellets. Although in adrenalectomized rats cortisone augments this antiinflammatory effect of jaundice, this effect of jaundice persists in the absence of adrenocortical hormones. In adrenalectomized rats the inhibitory effects of cortisone and jaundice on the formation of granulation tissue appear to be mutually independent and additive. The ability of jaundice to inhibit inflammatory processes in adrenalectomized rats treated with cortisone is not dependent upon a postulated hypothyroidism.
REFERENCES

Baker, W. P. (1955). "Effects of Experimental Jaundice on Adrenal Cortical Activity in Rats." Doctoral Dissertation, Michigan $\square$ State University.

Gardner, F., Stewart, A., and MacCallum, F. O. (1945). Brit. med. $J$. $2,677$.

Hanssen, P. (1942). Acta med. scand., 109, 494. Hanssen, P. (1942). Acta med. scand., 109, 494 . 12, 275.

Hench, P. S. (1933). J. Amer. med. Ass., 101, 1265. (1934). Ann. intern. Med., 7, 1278.

Hershberger, L. G., and Hansen, L. M. (1959). Anat. Rec., 134, 579. Hirvonen, M., and Räsänen, M. A. (1954). Acta endocr. (Kbh.), 16, 59 .

Holden, ${ }^{169}$. and Adams, L. B. (1957). Proc. Soc. exp. Biol. (N.Y.), 으 95, M. and Adams, L. B. (1957). Proc. Soc. exp. Biol. (N.Y.), $95,364$.

King, E. J. (1951). "Micro-analysis in Medical Biochemistry", $\mathcal{C}$ 2nd ed., p. 37. Churchill, London.

Marine, D., Manley, O. T., and Baumann, E. J. (1924). J. exp. $\vec{\bigcirc}$ Med., 40, 429.

Meier, R., Schuler, W., and Desaulles, P. (1950). Experientia (Basel),

Meyer, R. K., Stucki, J. C., and Aulsebrook, K. A. (1953). Proc. Soc. exp. Biol.' (N.Y.), 84, 624

Meites, J. (1951). Ibid., 78, 692. (1952). Ibid., 81, 307.

Selye, H. (1950). "Stress. The Physiology and Pathology of Expo- $\vec{\infty}$ sure to Stress." Acta Inc., Montreal, Canada. (1954). Ann. rheum. Dis., 13, 102.

Sylvester, O., Hall, C. E., Leblond, C. P. (1944). J. Amer.

med. Ass., 124, 201.
Snow, J. E., and Hines, H. M. (1941). Proc. Soc. exp. Biol. (N.Y.), 46, 257 .

Stucki, J. C., and Meyer, R. K. (1955). Endocrinology, 57, 173.

Telkkä, A., and Kuusisto, A. N. (1954). Acta endocr. (Kbh.), 16, 221 .

Thompson, H. E., and Wyatt, B. L. (1938). Arch. intern. Med.,

Yates, F. E., Urquhart, J., and Herbst, A. L. (1958). Amer. J. $\frac{\mathbb{Q}}{3}$ Physiol., 195, 373.

Effets anti-inflammatoires de l'ictère par occlusion chez le rat

RÉSUMÉ

L'ictère par occlusion chez le rat inhibe la granulatiōing d'un tissu irrité par une implantation sous-cutané de boulettes de coton. Bien que chez des rats privés de leurs surrénales la cortisone renforce cet effet anti- $\bar{O}$ inflammatoire de l'ictère, celui-ci continue à s'exercer en l'absence des hormones surrénocorticales. Chez des $\mathbb{D}$ rats privés de leur surrénales, les effets inhibiteurs de la cortisone et de l'ictère semblent être indépendants l'un $\overrightarrow{\hat{O}}$ de l'autre et additifs. Le pouvoir anti-inflammatoire 3 de l'ictère chez des rats surrénalectomisés et traités par $\supset$ la cortisone ne dépend pas d'un hypothyroïdisme postulé.

\section{Efectos anti-inflamatorios de la ictericia obstructiva en la rata Sumario}

La ictericia obstructiva en la rata inhibe la granulación de un tejido irritado por una implantación subcutánea de pelotillas de algodón. Aunque en ratas suprar- 2 renalectomizadas la cortisona hace aumentar el efecto응 antiflogístico de la ictericia, éste persiste en la ausencia de las hormonas suprerrenales. En las ratas suprar- $\frac{D}{O}$ renalectomizadas, los efectos inhibidores de la cortisona y de la ictericia parecen aditivos e independientes el uno $\mathrm{N}$ del otro. El poder antiflogístico de la ictericia en las. ratas suprarrenalectomizadas y tratadas por la cortisona $\mathrm{N}$ no depende de un hipotiroidismo postulado. 